伊東市富戸に和忷るスキューバダイビング導入に伴ら地域社会の変容

池 俊 介 $^{*}$

キーワード：伊東市，スキューバダイビング，観光地域，地域社会，沿岸集落

\section{I はじめに}

第二次大戦後の高度経済成長期以降, 生活水準 の向上と余暇時間の増加に伴い, 日本の沿岸域に おけけレクリエーション活動が活発化するととも に, マリンレジャーの多様化が進んだ。なかでも スキューバダイビングは，1980年代に入ってか ら, 潜水器材の進歩により安全性・機能性が向上 したことや, ファッション化が進んだことなどに より，若年層を中心に急速に普及していった（日 本海洋レジャ一安全・振興協会編著, 1997, p.12 3)。その結果, 日本の現在のダイビング人口は約 90万人にまで達し1), スキューバダイビングは, わが国の主要なマリンレジャーとしての地位を確 立している。

こうしたダイビング人口の急増に伴い, 沿岸域 に抢けるダイビングスポットの開設が進み, 現在 では, 全国に178カ所にのぼるダイビングスポッ トが設置されるに至っている（運輸省海洋・海事 課, 1989, p.30)。こうした動向のなかで, 漁業 を生業の柱としてきた沿岸集落のなかには，ドラ スティックな地域変化を経験するものも出現して きた。例壳ば, 宮内（1998）は，沖縄県座間味島 を対象地域として，スキューバダイビングを軸と した観光産業の発達が, 雇用の場の拡大につなが り, 島嶼地域としては異例の人口増加をもたらし たことを報告している。また筆者らも，伊豆半島 北西端の沼津市大瀬崎を対象地域として, 従来の 海水浴客を主体とした民宿地域から通年型の「ダ イビング観光地」への変容の実態を明らかにした （池・有賀，1999）。これらの研究によって, 近年
のスキューバダイビングの地域的展開が，沿岸集 落に扣ける地域変化の重要な要因となりつつある ことは明らかとなった。しかし，いまだ調査事例 が少ないこともあり,その地域社会の変容の実態 が十分に解明されたとは言い難い状況にある。

また，スキューバダイビングの場合には，その 利用空間について沿岸漁業との競合が見られる が，いまだ漁業との間の具体的な調整システムが 確立して和らず（山下，1992，p.26）, 沿岸集落 の地域社会とダイバーとの軋軪が社会問題化して いる2）。その一方で, 沿岸漁業が衰退傾向にある 今日では, ダイビング事業による収益は, 漁協経 営の安定化と各組合員の所得水準の向上の切り札 として期待されて扣り（浜本・田中, 1997, p.35), 地域活性化の視点からも，ダイビング事業と地域 社会との安定した共存関係の形成が重要な課題と なっている。

そこで本稿では, 大都市近接型のダイビングス ポット3）として，東京大都市圏を中心に全国から ダイバーが来訪する伊豆半島東海岸の伊東市富卢 地区を研究対象地域として取り上げる（第 1 図）。 そして, ダイビングサービス進出の実態, 各種の ダイビング事業の経営内容, ダイビング事業の展 開が地域社会に与えた影響等を明らかにする作業 を通して，ダイビング事業と地域社会が共存して 行くらえでの問題点や，そのあり方についても考 察を加觉ることを目的とする。とくに富戸地区の 場合, 宿泊施設の付帯施設としてダイビングサー ビスが設置され両者が経営面で密接に結びついて いる沼津市大瀬崎地区（池・有賀, 1999）とは異 なり，宿泊施設とダイビングサービスの経営がそ

* 静岡大学教育学部 


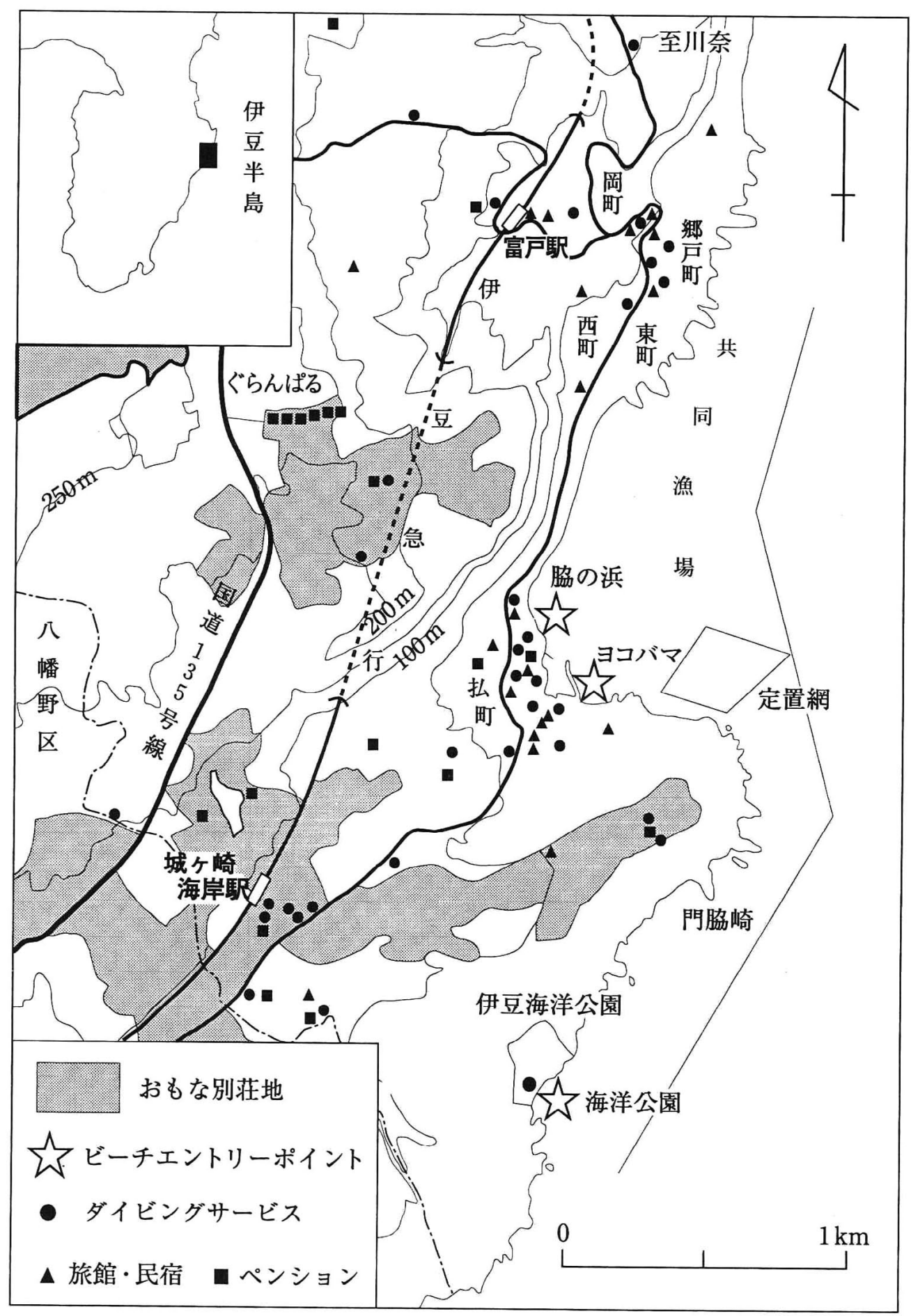

第1図 富戸地区におけるダイビング・宿泊施設の分布

実態調査および伊東市（1989）による。 
れぞれ独立している点に大きな特色が見られる。 そのため, 大瀬崎地区で得られた調査結果と比較 検討することにより，全国のダイビング観光地の 類型化を試みるらえでの重要な知見を提供し得る ものと考觉る。

富戸地区には，脇の浜・ヨコバマの 2 力所の ビーチエントリーポイントをもつ「富戸」と, 伊 豆海洋公園内からエントリーする「海洋公園」の 2 つのダイビングスポットが存在し（第 1 図）, 主要なものだけでも合計17カ所のダイビングポイ ントが沿岸に分布している。1964年, 伊豆海洋公 園内に伊豆海洋公園ダイビングセンター（当時の 名称は東拓アクアスポーックラブ）が創設され, 海洋公園は全国的にも早い時期から多くのダイ バーを集めていたが，とくに富戸港付近のダイビ ングスポットが開設された1988年以降，急速に来 訪ダイバー数が増加した。その結果, 現在の富戸 地区の年間来訪ダイバー数は，9 万3744人（1999 年）飞達し，富戸・海洋公園は，沼津市の大瀬崎 地区とならび，伊豆半島の中でも特に人気の高い ダイビングスポットとなっている。

江戸時代の藩政村としての富戸村は, 1889 （明 治22）年の町村制施行に伴い，池・八幡野・赤沢 の 3 村とともに偂島村を構成していたが，1955年 の対島村・伊東市の合併により, 伊東市の一地区 となった。現在の富戸区は，旧来ひとつの村落社 会を形成してきた郷戸町・東町・西町・岡町・払 町の 5 つの「町内」(第 1 図) に, 歴史の新しい 周辺の 3 つの「町内」を加えた 8 「町内」から構 成されている。元来の 5 「町内」の現在の世帯数 は合計555に過ぎないが，1960年代以降，いわゆ る「伊豆高原」に扣ける大規模な別荘地造成が進 められたほか，1980年代からはペンション等の宿 泊施設の開業が相次いだ結果, 流入人口が著しく 増加し，2000年 3 月31日現在の富戸地区（富戸区 に属さない別荘地等を含む）全体の人口は5621 人，世帯数は2471となっている。

\section{II＼cjkstart富戸地区における観光地化の進展}

\section{1 観光地化以前の生業形態}

a ) 半農半漁の村

静岡県漁業組合取締所（1894，p.46）によれ
ば，明治中期の富戸区は，総戸数152戸のうち漁 戸が150戸を占める「農業五分漁業五分」の半農 半漁の村であった。僅かな湾入を利用した小規模 な漁港しか持たない富戸では, 漁業の生産力は相 対的に低く，乙かも漁獲が不安定であったため， 農業への依存度も高くならざるを得なかった。

生業の柱の一つである漁業経営の内容は, 冬季 のイカ釣漁業を主体とし，それに30余戸による共 同経営のサンマ網，部落張のボラ網4）を組み合わ せたものだった（静岡県漁業組合取締所, 1894, p.45 49)。この部落張のボラ網に代表されるよ らに，当時の富戸に扣いては，強固な村落共同体 的な結合が維持されていた。

一方，漁業と並ぶ生業の柱であった農業経営 は，集落近辺の狭小な畑地での自給的な麦類・サ ツマイモの栽培を中心とするものであった。富戸 地区一帯は，大室山火山群の溶岩流で覆われて拉 り (葉室, 1978, p.439), 水田は僅か 3 ha程度し か存在しなかった。集落周辺には，三の原・先原 等と呼ばれる溶岩台地が広がっているが，これら 比較的広い緩傾斜地は, 主に薪炭材採取地・採草 地として利用されていた。これらの山林原野は, 1890年代末以降, 静岡県庵原郡や山梨県などから の入植者らによって，開墾が進められたが（富戸 史話編集委員会編，1969，p.55～61)，これら開 拓地と半農半漁の村としての富戸とは基本的に別 個の生活が営まれてきた。歴史の新しい3「町 内」（三の原・松尾・上野）は，これらの開拓集 落を基礎としている。

b ）海図から陸図一

大野 (1959，p.217～222）は，海路を通して東 京と商品流通面で直結していた富戸が，1930年頃 を境に陸路を中心とするローカルな市場との結び つきを強めてゆく過程を,「海図から陸図へ」と いら言葉で表現している。そして，地方的な領域 での人口・商品の動きの活発化が，「部落的強制」 の存在をゆさぶる条件になったことを指摘してい る5)。

こうした過程の中で，上層漁家によるサンマ流 刺網の導入が本格化した大正期以降, 漁民層分化 が顕著となり，とくに深刻な不漁が続いた1930〜 1937年には，階層分化の傾向がいっそら促進され 
第 1 表 富戸漁協における水揚量等の推移

\begin{tabular}{|c|c|c|c|c|c|c|c|}
\hline \multirow[b]{2}{*}{ 年 } & \multicolumn{2}{|c|}{ 受託販売 } & \multicolumn{3}{|c|}{ 自営事業収入（千円） } & \multirow[b]{2}{*}{ 卸売物価指数 } & \multirow[b]{2}{*}{ 正組合員数 } \\
\hline & 量 $(\mathrm{kg})$ & 金額（千円） & 定置網 & 蓄養 & 計 & & \\
\hline 1958 & 352462 & 16926 & $\cdots$ & - & $\cdots$ & - & 299 \\
\hline 59 & 535527 & 19930 & $\cdots \cdot$ & - & $\cdot \cdot$ & - & 302 \\
\hline 61 & 1014321 & 36668 & $\cdots$ & - & $\cdot \cdot$ & 51.7 & 224 \\
\hline 65 & 1497982 & 72581 & 18843 & - & 43958 & 52.3 & 132 \\
\hline 66 & 1096547 & 78998 & 18006 & - & 59569 & 53.6 & 126 \\
\hline 67 & 702858 & 76613 & 30620 & 3066 & 59665 & 54.5 & 127 \\
\hline 68 & 317657 & 60589 & 26639 & 8430 & 63220 & 55.0 & 136 \\
\hline 70 & 454503 & 74875 & 30185 & 12783 & 83512 & 58.1 & 102 \\
\hline 71 & 265585 & 85932 & 41655 & 12215 & 89967 & 57.7 & 88 \\
\hline 72 & 383160 & 96546 & 41621 & 23222 & 112303 & 58.2 & 92 \\
\hline 73 & 224161 & 101595 & 43839 & 24468 & 125565 & 67.4 & 90 \\
\hline 74 & 269541 & 133264 & 59640 & 22158 & 180146 & 88.5 & 92 \\
\hline 75 & 221209 & 112713 & 48332 & 34613 & 168891 & 91.2 & 97 \\
\hline 76 & 311953 & 121676 & 57674 & 34579 & 163642 & 95.9 & 92 \\
\hline 77 & 326971 & 157504 & 90210 & 40133 & 205026 & 97.7 & 98 \\
\hline 78 & 231350 & 128744 & 65894 & 45473 & 173199 & 95.2 & 94 \\
\hline 79 & $\cdot \cdot$ & $\cdots$ & 93098 & 88728 & 240189 & 102.2 & 84 \\
\hline 80 & 350689 & 163140 & 78515 & 97163 & 245916 & 120.3 & 85 \\
\hline 81 & 341522 & 221281 & 126153 & 92313 & 271512 & 122.0 & 83 \\
\hline 82 & 230243 & 187830 & 108164 & 73712 & 219705 & 124.2 & 73 \\
\hline 83 & 261513 & 170880 & 88609 & 111579 & 239743 & 121.4 & 74 \\
\hline 84 & 444131 & 200239 & 79820 & 102442 & 247106 & 121.1 & 79 \\
\hline 85 & 369590 & 200039 & 77341 & 122864 & 270865 & 119.7 & 81 \\
\hline 86 & 357218 & 192722 & 91674 & 107303 & 247539 & 108.8 & 66 \\
\hline 87 & 395284 & 204317 & 99521 & 132110 & 278240 & 104.7 & 69 \\
\hline 88 & 347695 & 172922 & 77941 & 105374 & 224684 & 103.6 & 67 \\
\hline 89 & 193071 & 176485 & 78621 & 98859 & 207329 & 106.3 & 62 \\
\hline 90 & 199087 & 175059 & 81083 & 163599 & 271329 & 108.5 & 59 \\
\hline 92 & 355557 & 195192 & 94771 & 158839 & 278201 & 106.1 & 56 \\
\hline 93 & 303109 & 197940 & 98717 & 151983 & 274042 & 103.0 & 52 \\
\hline 94 & 411735 & 136041 & $\cdots$ & $\cdots$ & 136041 & 101.0 & 51 \\
\hline 95 & 790675 & 218050 & $\cdot \cdot$ & $\cdots$ & 178062 & 100.0 & 51 \\
\hline 96 & 513885 & 143430 & $\cdots$ & $\cdots$ & 102659 & 100.1 & 54 \\
\hline 97 & 605070 & 139726 & $\cdots$ & $\cdots$ & 112026 & 101.6 & 52 \\
\hline 98 & 362479 & 152055 & $\cdot \cdot$ & $\cdots$ & 118313 & 100.0 & 52 \\
\hline 99 & 303189 & 118854 & $\cdots$ & $\cdots$ & 85566 & $\cdots$ & 50 \\
\hline
\end{tabular}

*伊東市漁協に合併した1994年以降の自営事業収入の内訳は不明。

伊東市漁協富戸支所資料拈よび経済企画庁（2000）p.412kよる。 
た。そして、このような階層分化の進展を背景と して, 早くも1925（大正14）年頃から出稼者が増 加しはじめ, 1930年代には多数の出稼者が京浜地 区や満州（当時）に流出した（大野，1959, p.221)。

また，養虫・温州みかん等の商品作物が導入さ れたのも,この頃であった。とくに, 山梨県出身 の入植者が持ち込んだといわれる養虫は, 大正中 期には富戸区の大部分の世帯に普及し，一時は重 要な現金収入源となったが，藏価の低迷等により 1930年代後半には著しく衰退した。生産性の低い 狭小な耕地での農業は，こうした商品作物の導入 などの努力にもかかわらず，漁業から流出した労 働力を吸収するには不十分であり，労働力が出稼 等の形で他業種へ移行する傾向は, その後も続く ことになった（大野，1959，p.214）。

c）第二次大戦後の農・漁業の衰退

第二次大戦直後には, イカの記録的な豊漁が続 き, 漁船数も1945〜 49年の 5 年間に 40 隻から91隻 にまで増加した。しかし，1952年からイカの漁獲 量が激減し，また他の主要魚種のサンマ・サバ・ アジも不漁が続いたため, 1955年頃には漁船を売 却して漁業以外に転職するものが続出した（大 野，1959，p.224）。1958年に実施された大野盛雄 （1959）の実態調査によれば, 富戸（岡町を除く） の252世帯中, 漁船を所有する漁業経営者（21世 帯）と商業経営者を除いた「労働者世帯」は171 世帯（約68\%）に達して扣り，このうち漁業労働 者のみの世帯は26世帯にすぎない。こうした数字 からも, 当時の漁獲量減少に伴ら, 漁業危機の深 刻さがうかがわれよら。

一方, 漁業収入が激減した1950年代後半には, 農業に活路を見い出すべく，養虫の衰退に伴って 1935年頃から植栽が本格化した温州みかんの栽培 が拡大していった。その結果，1960年までにみか ん園（成木のみ）は約50haにまで抁大し，1960年 度の生産額は5200万円に達した（富戸史話編集委 員会編，1969，p.52）。さらに1970年には, 全耕 地（70.8ha）の約94\%を樹園地（大部分がみかん 園）が占めるにいたり，温州みかん栽培が農業の 中心的な地位を占めるようになった。しかし， 1972年の温州みかんの全国的な価格暴落とその後
の価格低迷のなかで, 1980年代には温州みかん栽 培は著しく衰退し，樹園地面積は1980年には49.1 ha，95年には19.1haにまで減少した。

1960年代には，イルカの大漁をはじめとする好 漁が続き，1950年代に危機に陥っていた漁業経営 は，一時的に回復した。ところが，その後の富戸 漁協（現伊東市漁協富戸支所）の水揚量（受託販 売量）は再び減少に転じ，漁業は現在に至るまで 低迷を続けている（第 1 表）。漁協の自営事業は, 定置網経営による収益や1967年に開始されたイセ エビ・サザェ等の蓄養事業の収益の増加等によ り，比較的安定した収益をあげているものの，一 本釣・刺網漁業を主体とする個々の漁業者の漁業 経営は年々厳しさを増しており，高齢化もあい まって漁業者数（漁協正組合員数）は減少の一途 をたどっている（第 1 表）。富戸漁協組合員52人 を対象として実施されたアンケートの結果によれ ば（伊東市，1989，p.38），1世帯当り漁業収入 （1986年度）が500万円を超えたのは僅か 7 世帯に 過ぎず，とくに近年は漁獲量の減少による漁業経 営の悪化が顕著となっている。

\section{2 観光地化の進展}

a ）伊豆高原の別荘地開発

現在, 伊豆高原と呼ばれている大室山 $(581 \mathrm{~m})$ 麓一帯は，江戸期には 4 村（富戸・池・八幡野・ 赤沢）の入会林野であったが, 1914 (大正 3 ) 年 の部落有林野統一事業の実施により, 約2178町歩 が旧対島村の村有林に編入された（伊東市史編纂 委員会編, 1958, p.669)。この村有林は, 1955年 の伊東市への合併時に旧 4 村に再配分され，さら に「町内」・個人への分割が進められたが，それ を契機に観光開発業者への土地売却が急速に進む こととなった6)。

伊豆高原に扣ける最初の大規模な観光開発は, 1959年に富戸区から土地売却を受けて東拓観光開 発が造成した伊豆シャボテン公園であった。1961 年に伊豆急行が開通するとともに観光開発は活発 化し，とくに1960年代には大規模な別荘地の開発 が行われた（山村，1974，p.161）。別荘地の開発 面積は，東拓観光開発（1960～1972年）約260万

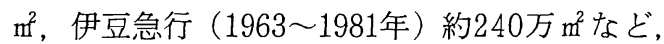




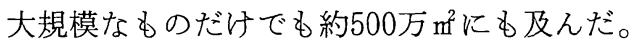

これらの別荘地には, 個人別荘だけでなく会 社・地方自治体の保養施設も多く建設され, 伊豆 急「伊豆高原別荘地」内だけでも保養施設は50力 所を数えた。そして、こらした保養施設の利用者 の増加は, 1963年に開業した伊豆海洋公園等の観 光施設の建設とともに, 伊豆高原を訪れる観光客 数の増加に大きく貢献することとなった。実際,

伊豆高原の別荘地分譲が進められた1965～1974年 の 10 年間に, 伊東市の観光客数 7 ） は 417 万人から 609 万人へと約 1.5 倍にまで増加して和り，この時 期に伊豆高原は首都圏の主要な観光地域としての 地位を確立した。

一方, これらの観光開発事業に伴ら土木建設需 要の増加や各種の観光施設の開業は, 富戸区の住 民にとって恰好の就労の場を提供することなっ た。1985年の国勢調査によれば，富戸地区の男性 就業者 1155 人の内訳は, サービス業 $34.3 \%$, 卸 売・小売業, 飲食店 $17.4 \%$, 建設業 $16.4 \%$, 農業 $9.4 \%$ ，漁業1.8\%となっており，観光地化に伴っ て就業構造は大きく変化することになった。

b ）宿泊施設の開業

伊豆高原の別荘地開発に伴い, 1968年の城ヶ崎 ピクニカルコースの開設や宿泊施設「臨海荘」8) の開業など, 富戸集落およびその近辺に拉ける観 光施設の建設も進んだ。1960年代中頃までは, 富 戸集落の宿泊施設は，2 軒の釣宿のみであった が, 海水浴客を主体とする観光客数の増加を背景 として，とくに1960年代後半から1970年代にかけ て民宿・旅館の開業が相次いだ。富戸地区に括け る宿泊施設の開業年を具体的に示すと，1966〜 1970年に 7 軒の民宿・旅館が, 1971〜80年にかけ て民宿・旅館15軒，ペンション1軒が開業して拈 り，とくに1970年代を中心に民宿・旅館数が急增 したことが分かる。

現在までに富戸地区で開業した民宿・旅館は合 計26軒にのぼるが(らち6軒はすでに廃業)，こ れらの民宿・旅館のらち，富戸区出身者による経 営は20軒に達している。また, 開業当初から専業 的な営業を行っていたのは 8 軒のみで，その他は 漁業・農業拈よび土木建設労務との兼業として始 められたものであった。これらのことからも，当
時の民宿・旅館の開業が, 漁業・みかん農業の不 振を契機としたものであったことが窥われる。

1980年代前半までの民宿・旅館の経営は， 7 ・ 8 月の海水浴客が年間宿泊客数の 5 割近くを占め ていたが，夏季以外に拈いても，釣客のほか，別 荘・保養所の建設工事などに携わる観光目的以外 の宿泊客も多かった。1980年代後半には, 工事の 完了とともに建設業関係者の宿泊が減少したが, その一方でスキューバダイビングを目的とする宿 泊客が増加していったため, 民宿・旅館経営は比 較的順調に推移してゆくこととなった。

一方, 民宿開業ラッシュが終わった1980年代後 半には, ペンションの開業が著しく進み, 1990年 までに富戸地区沿岸部9）で16軒が開業した。現 在, 営業している22軒のペンションのらち, 富戸 集落中心部に存在するのは僅か 1 軒で, 多くのぺ ンションが富戸集落周辺もしくは別荘分譲地内に 立地している（第 1 図）。また, 経営者も富戸区 以外の出身者で占められて括り10), ペンションの 場合, 地元の村落社会との地縁的な結びつきが極 めて薄いのが特徵となっている。

\section{III スキューバダイビングの導入と展開}

\section{1）ダイビングスポットの開設}

富戸地区に括けるスキューバダイビング発展の

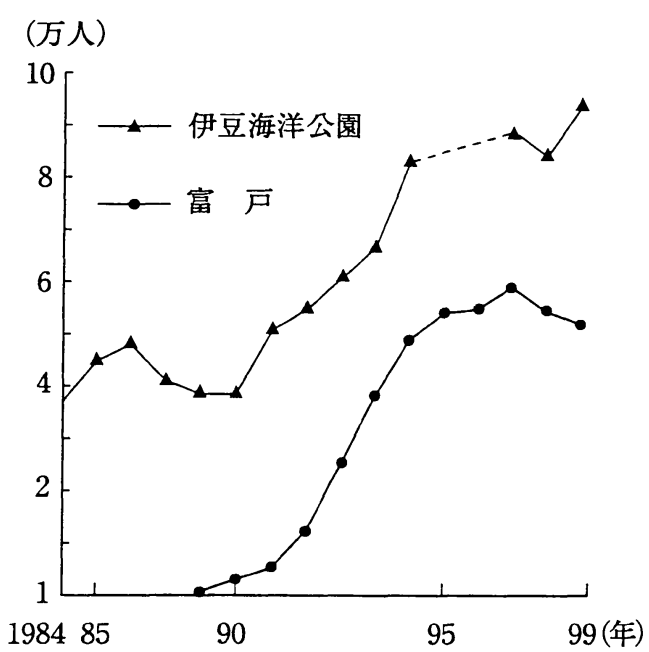

第 2 図 富戸地区における来訪ダイバ一数の変化 伊豆海洋公園ダイビングセンターおよび伊東市漁協富戸支 所資料による 
契機となったのは, 1964年の伊豆海洋公園ダイビ ングセンターの開設であった。伊豆海洋公園ダイ ビングセンターは, 同年, 地先水面の共同漁業権 を有する富戸漁協（当時）と交渉を進め, 伊豆海 洋公園付近の幅 $300 \mathrm{~m}$, 沖合 $30 \mathrm{~m}$ の海域にダイビ ングスポットが開設された11)。当時の日本には,

正式に開設されたダイビングスポットは皆無に近 かったため, 全国からダイバーが集まり，その後 の日本のスキューバダイビングの発展に大きく貢 献することとなった。ダイビングスポット開設以 降, 海洋公園では順調に来訪ダイバー数が増加 し、いまだ全国のダイビング人口が約 6 万 1 千人 に過ぎなかった1986年の時点で, 年間約 4 万 8 千 人ものダイバーを集めていた（第 2 図）。まさに 海洋公園は, 日本のダイビングスポットの草分け 的な存在であった。

こうした海洋公園に抢ける大量のダイバー流入 に刺激され，1988年に富戸漁協は富戸港近くにダ イビングスポットを新設し, 直営の富戸ダイビン グサービスを開業して, 本格的にダイビング事業 に乗り出すことになった。これにより, 従来の海 洋公園に加え,「脇の浜」「ヨコバマ」(第 1 図) からもビーチエントリーが可能となった潘か, 富 戸港からの漁船を利用したボートダイビングも可 能となり，富戸地区はダイビングスポットとして の充実度を格段に増すことになった。

その後も漁協では, ダイビング関連施設の整備 を進めることによって，より多くのダイバーの集 客を目指した。扣もな施設整備事業としては, ダ イバーための休䕀室・研修室や温泉施設の建設, ビーチェントリーのためのスロープの整備などが あり，1989〜99年に約5974万円が設備投資のため に使用されてきた。とくに，ダイビング終了後の 冷えた身体を暖めるための温泉施設は好評で, こ うした設備投資がさらに多くのダイバーの集客に 結びついた。

実際，設備投資が積極的に行われた1990年代前 半には, 富戸の年間来訪ダイバー数は著しい増加 を遂げ，1995年には 5 万人を突破した（第 2 図）。 近年は増加率こそ低下しているものの，1999年に は海洋公園を含めた富戸地区全体の年間来訪ダイ バー数は約 9 万 4 千人を記録し，全国でも有数の
ダイビングスポットにまで成長した。

こうした来訪ダイバー数の急増は, 富戸漁協の 事業収益の増加にも貢献し，1965年に7076万円で あった総事業収益は1993年には 6 億4483万円にま で増加した。また，事業収益の内訳について見る と，1980年代には自営事業収入が全体の60～70\% を占めたが, 来訪ダイバー数が急増した1993年に は，自営事業の占める割合は $43 \%$ まで低下する一 方，ダイビング事業収入に相当する「利用事業」

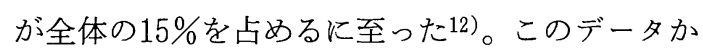
らも明らかなよらに, 漁協経営の行き詰まりを打 開すべく推進されたダイビング事業は, 実際に予 想を上回る注どの多額の収益を漁協にもたらすに 至って扣り，いまや漁協経営にとってダイビング 事業は必要不可欠な部門を構成している。

な拉,ダイビングスポットの開設に当っては, ダイバー流入に伴う漁業被害の増加が心配され (浜本・田中, 1997, p.35), それが開設を躊躇さ せる要因となる場合が多い。しかし，富戸地区に 扣いては，イセエビ刺網の漁期である9月15日〜 5 月 15 日の午後 3 時以降は潜水禁止にするなどの 措置をとることで, 漁業者との共存が図られてお り，現在まで問題となるような漁業被害も報告さ れていない。むしろダイビング事業は, 漁協経営 に大きく寄与しているばかりか, 後述するように 漁業者にもボートダイビング営業を通じて経済的 恩恵を与えて扣り, 漁協・漁業者とダイバーとの 関係はかなり良好な状態にある。

\section{2) ダイビングサービス ${ }^{13)}$ の進出と経営内容}

第 3 図は, 富戸地区におけるダイビングサービ ス数の推移を示したものであるが, 富戸漁協によ るダイビング事業が本格的に開始されて来訪ダイ バー数が増加した1990年代以降, ダイビングサー ビスの著しい進出が見られたことが分かる。とく に, 1996年には, 僅か 1 年間に 8 軒のダイビング サービスが新たに開業しており，現在では35軒も のダイビングサービスが富戸地区で営業してい る。

これらのダイビングサービスの経営状況の概要 を整理したのが第 2 表であるが，その経営内容か らダイビングサービスは次の 4 つの類型に区分で 


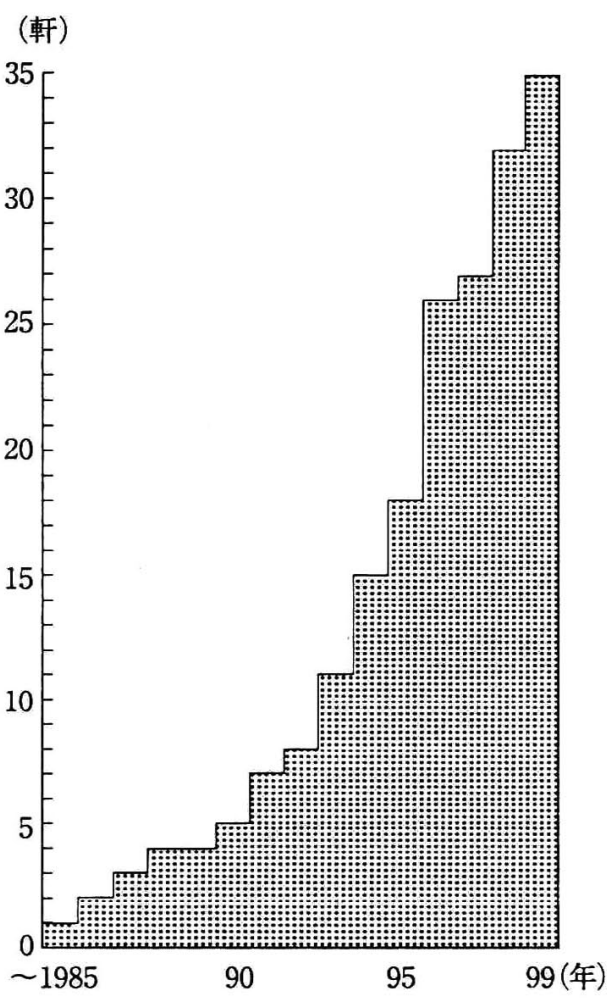

第 3 図 ダイビングサービス数の推移

聞尚还み調査による

きる。第 1 の類型は, ダイビングスポットを管理 する漁協の直営で, 施設 (更衣室・温泉等) 利用 料の徵収、タンク貨貸・ボート利用の受付を主要 な業務とするもので, 経営者番号(1)のみがこの類 型に入る。このダイビングサービスは，いわば漁 協のダイビング事業の空口であり，そのためガイ ドや講習などの業務は全く行っていない。

第 2 の類型は, 漁協からタンクのエア充填業務 を請負い，ガイド・講習業務とともに、それを主 要な業務の一つとする(2)と(3)である。この2 軒は いずれる開業時期が早く、スキューバダイビング に関する専門的知識の提供等を通じて, 漁協によ るダイビング事業経営を実質的に支えてきたダイ ビングサービスである。タンクのエア充填業務 が，この 2 軒に独占的に認められているのも、こ らした事情による所が大きい。

第 3 の類型は，ダイビングッアーや講習の企 画・開催, 潜水器材の販売を中心に事業を展開し ている都市部のダイビングブロショップの現地拠
点（クラブハウス）としての機能を持つ11軒であ る。この類型に属するダイビングサービスの場 合、初心者を対象とした講習を業務の一つとして いるのが特徵である。

第 4 の類型は、都市部のダイビングプロショッ プと無関係な単独のダイビングサービスであり, 数の上では21軒と最も多い。この類型の場合, 多 くが 1〜2名の少人数の常勤スタッフにより運営 されて㧍り，ガイドを主たる業務としている。と くに近年急增しているのは, この類型に属する小 規模なダイビングサービスである。

筆者らが以前に調査した沼津市大瀬崎地区の事 例では, タンクのエア充填を主要な業務とするダ イビングサービスがほとんどを占め, その収入が 経営を大きく支えていた（池・有賀，1999，p.12）。 しかし，共同漁業権を持つ漁協が直接ダイビング 事業に関わっている富戸地区では, 漁協がタンク のエア充填を第 2 類型の 2 軒のみに依託し、タン ク賃貸料（1本当り一般2000円）加納入価格 （1本当り600円）を差引いた金額を漁協の収益と している。その結果，他のダイビングサービス は,タンクのエア充填業務に参入できず，ガイ ド・講習を主要業務とせざるを得なくなっている 14)。つまり，こうしたダイビング事業に対する漁 協の関与の強さが, 富戸地区の大部分のダイビン グサービスの業務内容をガイドと講習に特化させ ている原因といえよう。

また, 大瀬崎地区の場合, 大部分のダイビング サービスは旅館・民宿の付帯施設といら性格が強 く, 宿泊施設経営者が経営安定化のためにダイビ ングサービスを開業するケースが一般的であった が，富戸地区では宿泊施設に併設されているもの は、ペンションを兼業している 3 軒に過ぎない (第 2 表)。また，過去に民宿経営者の子息がダイ ビングサービスを開業した事例が 1 件あったが, 現在では民宿を廃業してダイビングサービスのみ の営業となっている。このように，宿泊施設とダ イビングサービスが個々に独立した経営を行って いる点に，富戸地区の特徵があり，それが後述す るようにダイビングサービスと宿泊施設との間の 競合関係を生む原因となっている。 
第 2 表 ダイビングサービスの経営状況

\begin{tabular}{|c|c|c|c|c|c|c|}
\hline 類型区分 & 経営者番号 & 常駐スタッフ数 & アルバイト数 & 主要業務 & 宿泊施設兼業 & 都市部店舗の有無（場所） \\
\hline $\mathrm{I}$ & (1) & 2 & $2 \sim 3$ & A & $x$ & $\times$ \\
\hline II & $\begin{array}{l}\text { (2) } \\
\text { (3) }\end{array}$ & $\begin{array}{c}11 \\
6\end{array}$ & $\begin{array}{c}2 \sim 3 \\
5\end{array}$ & $\begin{array}{l}\text { B C C D } \\
\text { B C D }\end{array}$ & $\begin{array}{l}0 \\
\times\end{array}$ & $\begin{array}{l}x \\
\times\end{array}$ \\
\hline III & $\begin{array}{l}\text { (4) } \\
\text { (5) } \\
\text { (6) } \\
\text { (7) } \\
\text { (8) } \\
\text { (9) } \\
\text { (11) } \\
\text { (11) } \\
\text { (12) } \\
\text { (13) } \\
\text { (14) }\end{array}$ & $\begin{array}{l}2 \\
2 \\
2 \\
2 \\
2 \\
2 \\
2 \\
1 \\
1 \\
0 \\
0\end{array}$ & $\begin{array}{c}0 \\
0 \\
5 \sim 6 \\
2 \sim 3 \\
0 \\
8 \\
4 \\
3 \\
1 \\
0 \\
1\end{array}$ & $\begin{array}{l}C D \\
C D \\
D \\
C D \\
C D \\
C D \\
C D \\
C D \\
C D \\
C D \\
C D\end{array}$ & $\begin{array}{l}\times \\
\times \\
\times \\
0 \\
\times \\
\times \\
\times \\
\times \\
\times \\
\times \\
\times\end{array}$ & $\begin{array}{l}\bigcirc \text { (東京) } \\
\bigcirc \text { (神奈川) } \\
\bigcirc \text { (栃木) } \\
\bigcirc \text { (東京) } \\
\bigcirc \text { (神奈川) } \\
\bigcirc \text { (長野) } \\
\bigcirc \text { (東京) } \\
\bigcirc \text { (東京) } \\
\bigcirc \text { (東京) } \\
\bigcirc \text { (東京) } \\
\bigcirc \text { (東京) }\end{array}$ \\
\hline N & $\begin{array}{l}\text { (15) } \\
\text { (16) } \\
\text { (17) } \\
\text { (18) } \\
\text { (19) } \\
\text { (20) } \\
\text { (21) } \\
\text { (22) } \\
\text { (23) } \\
\text { (24) } \\
\text { (25) } \\
\text { (26) } \\
\text { (27) } \\
\text { (28) } \\
\text { (29) } \\
\text { (30) } \\
\text { (31) } \\
\text { (32) } \\
\text { (33) } \\
\text { (34) } \\
\text { (35) }\end{array}$ & $\begin{array}{l}6 \\
5 \\
3 \\
2 \\
2 \\
2 \\
2 \\
2 \\
2 \\
2 \\
2 \\
2 \\
2 \\
1 \\
1 \\
1 \\
1 \\
1 \\
1 \\
1 \\
1\end{array}$ & $\begin{array}{c}2 \sim 3 \\
2 \\
4 \sim 5 \\
1 \\
5 \\
1 \\
0 \\
0 \\
2 \sim 3 \\
0 \\
0 \\
2 \\
2 \\
3 \\
0 \\
2 \\
1 \\
0 \\
1 \\
3 \sim 4 \\
0\end{array}$ & $\begin{array}{l}\text { CD } \\
C D \\
C D \\
C \\
C \\
C \\
C \\
C \\
C \\
C \\
C \\
C \\
C \\
C \\
C \\
C \\
C \\
C \\
C \\
C \\
C\end{array}$ & $\begin{array}{l} \\
\times \\
\times \\
\times \\
\times \\
\times \\
\times \\
\times \\
\times \\
\times \\
\times \\
\times \\
\times \\
0 \\
\times \\
\times \\
\times \\
\times \\
\times \\
\times \\
\times \\
\times \\
\times\end{array}$ & $\begin{array}{l}\times \\
\times \\
\text { 閉鎖（東京） } \\
\times \\
\times \\
\times \\
\times \\
\times \\
\times \\
\times \\
\times \\
\text { 閉鎖（神奈川） } \\
\times \\
\times \\
\times \\
\times \\
\times \\
\times \\
\text { 闍鎖（東京） } \\
\times \\
\times \\
\times\end{array}$ \\
\hline
\end{tabular}

* A (施設利用料等の受付業務) B (タンク業務) C (ガイド業務) D (講習業務)

* 第 3 類型の場合, 常勤スタッフルバイト（繁忙期のみ）以外に, 都市部店舗から適宜スタッフが派遣される。

聞込み調査による。 
3 ）ダイビングサービス進出の要因

a）ダイビングスポットとしての優位性

富戸地区へのダイビングサービスの急速な進出 は，基本的には大量のダイバーの来訪によるとこ ろが大きい。その人気の高さを大きく支えている のが，富戸地区のダイビングスポットとしての優 位性であり，それは以下の 3 点に集約できよう。

第一は，東京大都市圏からの交通の利便性であ る。とくに伊豆半島のような大都市近接型のダイ ビングスポットの場合，土日を利用した短期間の ダイビングッアーが主となるため, 移動時間の短 さが重要な立地要因になる（池・有賀，1999, p.12)。その点, 富戸地区には伊豆急行の富戸 駅・城ケ崎海岸駅があり, 東京駅から鉄道利用で 2 時間程度で到達できる。とくに富戸地区の場 合，交通渋滞の心配のない鉄道を利用するダイ バーが多いが，それはこらした鉄道での移動時間 の短さによる所が大きい。また，自動車でも東京 からの所要時間は約 $2 \sim 3$ 時間程度で，きわめて 有利な条件に恵まれている15)。

第二は，ダイビングスポットとしての自然条件 の優位性である。富戸地区では，海岸線に沿って 溶岩流の先端が舌状に突出して，長さ $100 \mathrm{~m}$ 位の 小半島を数多く形成しているが（葉室，1978, p.439)，その延長線上の海底には「根」と呼ばれ る起伏が存在している。多数の根の存在は, 海底 地形の複雑さを生み，それが海中生物の豊富さに つながっている。とくに伊豆海洋公園付近は，潮 の出入りが激しいため，現在までに確認された魚 種が650種以上にのぼり（マリン企画, 1997, p.90),「日本のフィッシュウオッチングのメッ 力」と呼ばれている。こうした自然条件の良さ が, ダイバーにとっての大きな魅力となってい る。

第三は，潜水可能日数の多さである。伊豆半島 東海岸の場合,「ナライ」と呼ばれる強い北東風 が吹くと，海が荒れて潜水不能となる。しかし， 荒天による潜水不能日数は年間10日程度と少な く，ナライの時でも富戸港内や富戸地区に南接す る八幡野地区では潜水可能なため，ほとんど年間 を通してダイビングが可能である。とくに講習開 催の場合には，潜水可能日数の多さは重要な要件
となるが16)，その点でも富戸地区は恵まれた条件 を備觉ている。

b ）現地拠点としての重要性の増大

従来のダイビングショップの営業形態は, 都市 部にあるダイビングプロショップが講習やッアー を企画・集客し，ダイビングスポット近くの宿泊 施設を拠点にして実施するというのが一般的で あった。しかし，近年の景気低迷の影響で，高い 維持経費を要する都市部の店舗を縮小あるいは閉 鎖し，現地拠点としてのクラブハウスを自ら所 有・利用することにより，経費節減を図るダイビ ングショップが増加する傾向にある。こうした傾 向の中, とくにフィッシュウオッチング・ブーム が始まった1992年頃から，富戸地区にクラブハウ スを構えて常勤スタッフを置くダイビングプロ ショップが増加した。第 2 表の第 3 類型（11軒） のほとんどがこれに相当する。

また同じ頃から，潜水技能に優れ，海中生物に 関する知識が豊富なガイドが，独立して小規模な ダイビングサービスを開業する事例が目立つよう になった。第 2 表の第 4 類型（21軒）のうちの大 部分は，こうした性格を持つものである。魚種の 豊富な富戸地区では, フィッシュウオッチングを 目的とするダイバーが多いため，とりわけガイド 業務の必要性が高く，ダイバーの約 $80 \%$ がダイビ ングサービスを利用しているといわれる。そのた め, 富戸周辺海域での潜水経験が豊富で, ガイド としての高い能力さえ備えていれば，多くの顧客 を得ることが可能である。富戸地区の他のダイビ ングサービスのスタッフとしての勤務を経験し, その後に独立した事例が 9 軒にのぼるのも，こう した理由による。

なお，これらのダイビングサービスの開業に際 して，店舗が新築されるケースは一般に少なく， 既存の民家かアパートを借り，そこを住居を兼ね た店舗としている場合が多い。1990年代には，集 落内の借家物件も豊富で, 現地拠点の確保を希望 するダイビングサービスや大学のダイビングクラ ブ等の需要を見込んだアパートの新築も行われた ため，店舗を確保することは比較的容易であっ た。ダイビングサービスの多くが，富戸集落内に 存在するのも（第1図），そらした理由による所 
が大きい。

最近では，ダイバーの低料金志向が一段と強ま るなか,こうしたダイビングサービスの店舗に顧 客のダイバーを宿泊させるケースが一般化してお り, 宿泊施設をも兼ねた現地拠点の存在が重要性 を增しつつある。

C ）ダイビングサービスに対する優遇措置の存在 前述のように，富戸地区に执けるタンクのエア 充填業務は 2 軒のみに依託されており，他のダイ ビングサービスはエア充填業務による収益が期待 できない。そのぶん一般のダイビングサービスの 経営は㛜しくなるが，その一方で漁協は，タンク 使用料・施設使用料・ボート使用料等について, ダイビングサービス向けの特別価格を設定するな ぞの優遇措置も行っている。こうした優遇措置の 存在は，とくに小規模なダイビングサービスの経 営にとっては重要であり，もし漁協が一般ダイ バーと同等の価格設定を行ったとすれば，多くの ダイビングサービスでは経営の採算がとれないと いわれている。

例えば，漁協直営の富戸ダイビングサービスで は，各ダイビングサービスに対する施設使用料 （1 人当り 500 円）は一般の半額であり, タンク貨 貸料（1 本当り）は一般2000円に対し，1250円に 抑えられている。ボートダイビングの場合も，ガ イド・インストラクターの利用料は無料となって いる。また，伊豆海洋公園ダイビングセンターで も，タンク賃貸料（1 本当り）が一般1700円であ るのに対し，ダイビングサービスを通した場合に は700円である。

多くのダイビングサービスでは，ガイド料金に 一定以上の高価格を設定することが難しいため，

これら各種利用料とガイド料金のほか，宿泊料金 をもセットにしてパック料金を設定している場合 が多い。とくに，タンクのエア充填業務で利益を あげることができない大部分のダイビングサービ スでは，このような料金設定の工夫で利益率を高 め，それによって採算を維持していかざるを得な い。したがって，施設使用料等についての各ダイ ビングサービスに対する優遇措置の存在は, ダイ ビングサービスと漁協とが共存共栄を図るらえで 極めて重要な機能を果しており，結果的には，来
訪ダイバー数の増加によるダイビング事業収入の 増加といら形で, 漁協経営にとってもプラスに作 用している。

\section{Nスキューバダイビングと地域社会}

\section{1 漁協・漁業経営への影響}

a）漁協経営の安定化

漁協による施設使用料等の徵収空口となってい る富戸ダイビングサービスの年間収入の推移を見 ると，1988年には僅か約290万円であった収入は， 1990年代を通じて増加の一途をたどり，1994年以 降の年間収入は常に 2 億円以上を維持している。 ピークに当る1997年には約 2 億7939万円にまで達 し, 来訪ダイバー数がやや減少した1999年でも年 間収入は約 2 億 4604 万円にのぼっている。この データからも，ダイビング事業によって漁協にも たらされる収益の大きさが理解でさよう。

これらの収益の内訳を示したのが第 4 図であ る。収入源は, タンク賃貸料（1 本当り 2000 円), 施設使用料（1 人当り 1000 円），ボート手数料 （1 人当り 500 円），シャワー使用料（1 人当り 500 円)，駐車料（普通車500円）であるが，とくに高 い収入割合を占めるのはタンク賃貸料収入であ る。タンクの場合， 2 業者による納入価格（1本 当り600円）と貨貸料の差額が漁協の収入となる が, 各ダイバーのタンクの持込みを禁止している ため, ダイバー数の増加は，そのまま増収につな がることになる。現在では, タンク賃貸収入が収 入全体の 7 割以上を占めて扣り，漁協によるダイ ビング事業の中心的な存在となっている。

このように, 漁協がタンクのエア充填業務の許 可を 2 業者以外のダイビングサービスに与えず, 利潤率の高いタンク賃貸業務を独占的に維持して きたことが，漁協に対して多くの収益を保障し， 漁協経営の安定化をもたらしているとい方よう。 b ）漁業者によるボートダイビング営業

現在，伊東市漁協富戸支所には37隻の漁船が所 属しているが，このうち漁協所有船17）(11隻）と 自家用小型船（6隻）を除く20隻が個人の一本釣 漁業等の操業に使用されている。そして, そのう らの13隻がボートダイビング営業を行ら漁船とし て登録されて拈り ${ }^{18)}$, 漁協では各船のボートダイ 


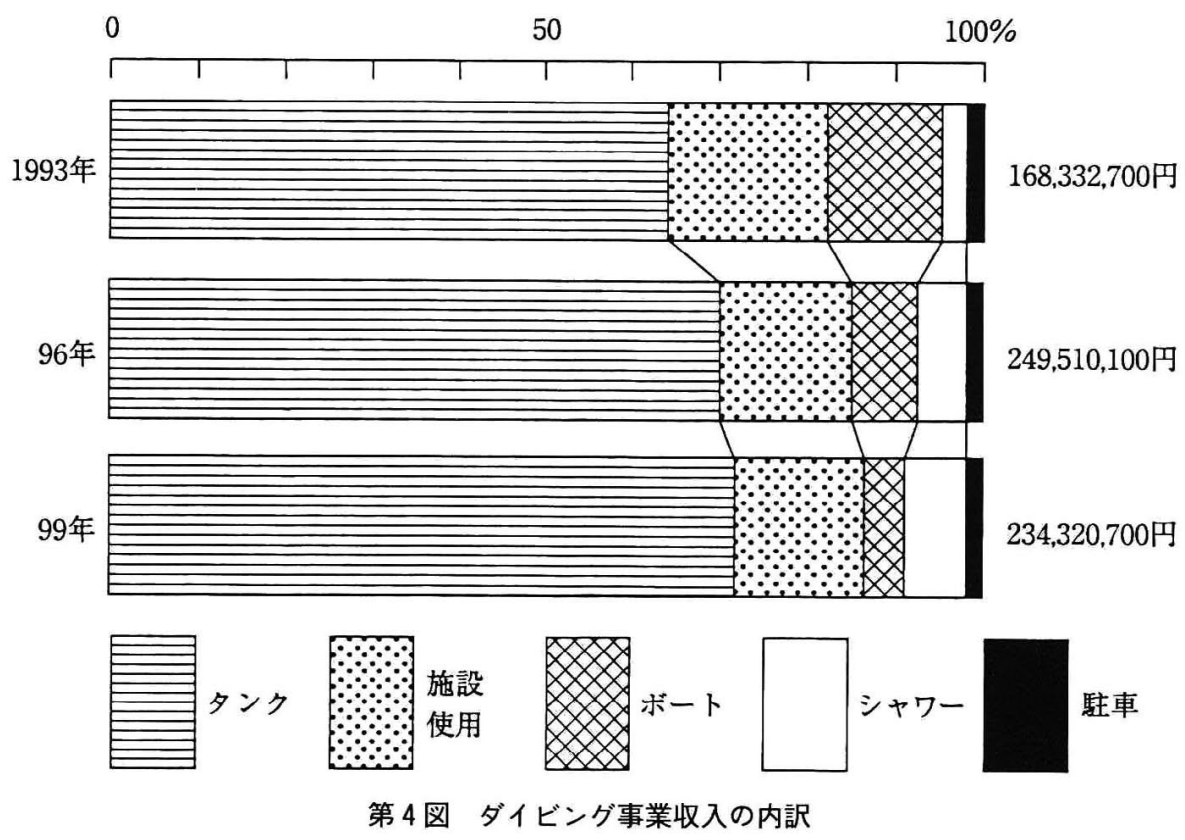

伊東市漁劦富戸支所資料による

第 3 表 ダイビングボートの稼働状況（1999年）

\begin{tabular}{|c|c|c|c|c|c|c|c|}
\hline \multirow[b]{2}{*}{ 番 号 } & \multicolumn{2}{|c|}{ ボート } & \multicolumn{2}{|c|}{ ハーフボート } & \multirow[b]{2}{*}{ 出労日数 } & \multirow[b]{2}{*}{ 收 入 (千円) } & \multirow[b]{2}{*}{ 漁業種類 } \\
\hline & 回 数 & 人 数 & 回 数 & 人 数 & & & \\
\hline (1) & 121 & 957 & 0 & 0 & 62 & 1914 & $\mathrm{ABC}$ \\
\hline (2) & 79 & 555 & 28 & 219 & 45 & 1220 & A \\
\hline (3) & 72 & 422 & 30 & 194 & 47 & 941 & A \\
\hline (4) & 71 & 412 & 38 & 226 & 46 & 937 & $\mathrm{ABC}$ \\
\hline (5) & 64 & 380 & 31 & 213 & 35 & 867 & A B \\
\hline (6) & 66 & 390 & 20 & 138 & 41 & 849 & A B \\
\hline (7) & 60 & 391 & 17 & 102 & 30 & 833 & A \\
\hline (8) & 68 & 400 & 0 & 0 & 35 & 800 & $\mathrm{ABC}$ \\
\hline (9) & 38 & 229 & 8 & 54 & 22 & 485 & $\mathrm{AC}$ \\
\hline (10) & 45 & 221 & 8 & 51 & 29 & 468 & A B \\
\hline (11) & 11 & 76 & 4 & 29 & 8 & 167 & A B \\
\hline (12) & 3 & 13 & 1 & 3 & 5 & 28 & $\mathrm{AB}$ \\
\hline (13) & 0 & 0 & 1 & 6 & 1 & 3 & $A D$ \\
\hline
\end{tabular}

*A (一本釣漁業) B (刺網漁業) C (敷網漁業) D (採介藻漁業)

伊東市澳協富戸支所資料による。

ビング収入が可能な限り均等になるよう、輪番制 でダイビング客を配分している。しかし実質的に は，ボートダイビング営業を行っている漁船の稼 動状況を整理した第 3 表のように，年間収入は約 191万円から 3 千円まで，かなりの幅がある。こ の年間収入の差は, 基本的には, 漁業とボートダ イビング営業のいずれに重点を置くかといら経営
方針の違いによって生じている。例えば、ボート ダイビング営業を中心とする(1)では, 自らの輪番 をキャンセルした日数は年間11日に過ぎず。その らち漁業を理由としたキャンセル日数は僅か 1 日 のみである。それに対して12は，漁業との競合等 による自己都合によるキャンセル日数が年間52日 にまで達し，土日以外でも利用客が多い繁忙期の 
8 月に拈いてさえ, キャンセル日数は 8 日に及ん でいる。

1999年のボートダイビング営業の 1 隻当り年間 平均収入は約73万円であるが, 一本釣漁船（20 隻）の 1 隻当り水揚金額の平均は約 166 万円で, 漁業収入に比べてボートダイビング営業の収入割 合は相対的に低い。しかし，ボートダイビング営 業は，漁業を補完する安定した収入源として，い まや漁業者にとって重要な存在となっている。と くに, 実際の稼動日数の少なさ（平均31日）や, 漁労に比べてはるかに軽労働であることを考学れ ば19)，ボートダイビング営業は漁業者にとってき わめて効率の良い仕事である。漁業者の高齢化対 策といら視点からも, その将来性は高く評価され て然るべきであろら。

しかし, 全体のダイビング収入に占めるボート 收入の比率の低下にも表れているよらに（第 4 図)、ボート利用者数は9301人（1993年）から5079 人（1999年）へと近年かなり減少している。これ は, ビーチエントリーで到達可能なダイビングポ イントと, ボートで案内する遠いダイビングポイ ントとの間の海中景観の質的な差異が少なく， ボートダイビングの魅力が相対的に薄いことが原 因といわれている。とくに近年では不景気のた め, 費用のかかるボートダイビングが敬遠される 傾向にあり,ボート利用者の減少に拍車をかけて いる。

こうしたボート利用客の減少は, ボートダイビ ング営業への依存度が高い漁業者だけでなく, 漁 協にとっても手数料収入の減少につながり，その 影響は深刻である。そのため漁協では, ボート利 用客に対して, タンク賃貸料・管理費の值引き サービスを行らなど20)，ボート利用客の拡大を 図っているが，大きな効果があがっていないのが 現状である。

\section{2 宿泊施設経営への影響}

第 5 図は, ダイビングスポットとしての富戸に 打ける来訪ダイバ一数の季節変動を示したもので ある。この図からも明らかなように，7・8月に 著しく集中する海水浴とは異なり，スキューバダ イビングは海洋性レクリエーションの中では季節

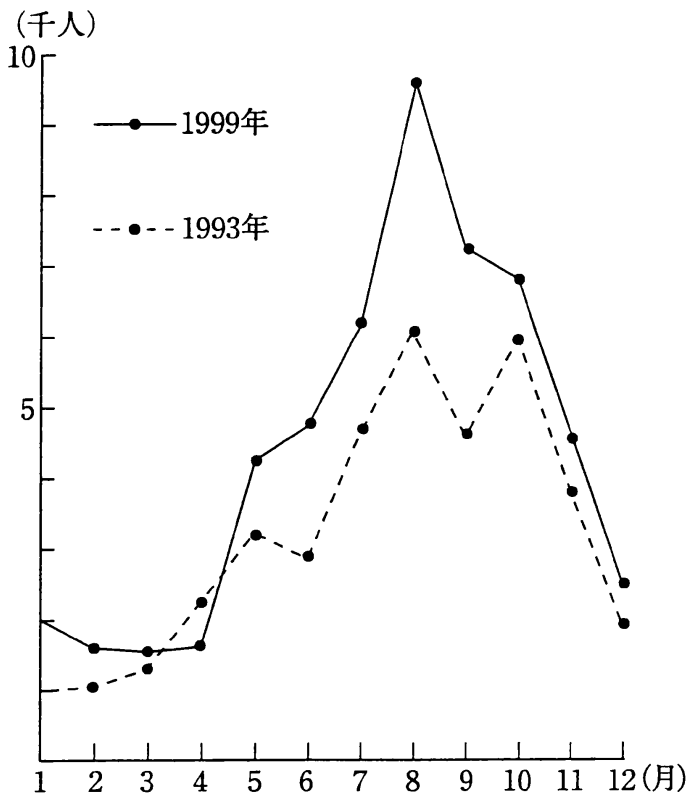

第 5 図 来訪ダイバー数の季節変動

伊東市漁協富戸支所資料による

的な入込客数の変動が少ない点に特色がある。そ のため，海水浴客に大きく依存してきた民宿に とって, スキューバダイビングの導入は, 宿泊客 を増加させ経営の安定化をもたらすものとして歓 迎された。実際に，1980年代後半から民宿・旅館 の宿泊客に占めるダイバーの割合は次第に増加 し, 宿泊施設経営の安定化に大きく貢献すること となった。

ただ，全ての旅館・民宿がダイバー客を積極的 に受け入れてきたわけではなく、現在の富戸地区 の20軒の旅館・民宿のらち 7 軒は, 宿泊客に占め るダイバーの割合が極めて低く，一般客や釣り・ ゴルフを目的とする宿泊客が大半を占めてきた。 とくに，民宿よりも料金設定の高い旅館にはこう した傾向が強く，むしろダイバー客の宿泊を好ま ない場合の方が多い。これは, 設備・サービスの 質よりも料金の低廉さを志向し，大部屋で夜遅く まで歓談を楽しむといら，学生の「合宿」的な䨌 囲気を好むダイバー客の体質による所が大き い21)。また，同様な理由で，料金設定が相対的に 高く小部屋が多いペンションも, 大量のダイバー 流入による恩恵にほとんど浴していない。その結 果, ダイバー客を主体とする民宿・旅館と，それ 
以外の宿泊施設との間に一種の「すみわけ」が形 成されてきた。

しかし1995年頃から，当初はダイビング・ッ アーの宿泊先として民宿・旅館を利用していたダ イビングプロショップの中に，経費の節減を目的 として，民宿を営んでいた民家を借上げて専用の クラブハウスとする事例が見られるようになっ た。とくに不景気が続く近年では，ダイバーの低 料金志向がいっそう強まり，ガイドを主要業務と する小規模なダイビングサービスでも，顧客であ るダイバーに宿泊サービスを提供する事例が一般 化している。また，東京大都市圏からの時間距離 が短いため，日㷌りでダイビングを楽しむダイ バーも増加しており，宿泊施設を利用するダイ バーが急激に減少しつつある。

こうした宿泊施設を利用するダイバーの大幅な 減少は，ダイバー客を主体としてきた民宿・旅館 の経営を著しく圧迫している。とくに, ダイバー 客に特化してきた民宿・旅館は，低料金ではある が設備・サービスの質が劣る場合が多く，ダイ バー以外の客層を獲得することが難しい。なかに は，後継者がないまま廃業を余儀なくされる民宿 も出現しつつある。そのため，顧客ダイバーを無 許可で宿泊させ，宿泊客を奪う結果となっている ダイビングサービスに対して, 反感をつのらせる 民宿・旅館経営者が増えている22)。さらに, ダイ バー客に依存していない旅館・民宿やペンション にとっても, 従来は海水浴客に利用されてきた富 戸港近くの磯浜がダイバーに占領されてしまい, 実質的に海水浴客が排除されてしまっているた め, ダイバーの存在を快く思っていない経営者が 多い。

沼津市大瀬崎の場合は, 宿泊施設経営者がダイ ビングサービスを併設する事例が圧倒的に多く， ダイバーの増加は宿泊客の増加に直接に結びつい ていたが（池・有賀，1999，p.10１1）, 富戸地 区では両者が独立した経営を営んでいるため, ダ イビングサービスと宿泊施設との関係は当初から 稀薄であり ${ }^{23)}$ ，それが宿泊施設とダイビングサー ビスとの対立をいっそう深める結果となってい る。

\section{3 伝統的村落社会との関係}

富戸区には「一戸権」といら制度が存在し，一 戸権所有者は，入会林野に関する収益の分配を受 けることができた㴗か，実質的には富戸区の下部 組織としての性格をもっていた漁業組合の組合員 として，ボラ網の利益の配当を受けることもでき た。いわば一戸権は，直接的に区の経営する事業 への参加を規定しており，一戸権所有の有無が社 会生活や経済活動に大きな影響を与えてきた24) （大野，1959，p.167）。

1948年の水産業協同組合法の制定に基づく漁業 協同組合の成立に伴い，漁業組織としての富戸漁 協と富戸区は形式的には分離されることになった が，漁業に従事しない一戸権所有者にも準組合員 として漁協の一員となることが認められ，新しい 漁協制度の中での古い村落共同体の温存が図られ た。現在でも，伊東市漁協富戸支所の組合員 493 名のらち443名が準組合員で占められ，漁協組合 員の中に多くの非漁業者が含まれているのも，こ のよらな経緯による。したがって，富戸区に拈い ては, 小栗 (1983, p.180-187) のいら地区漁協 の「村」化が顕著に見られたと言えよう。

ところが, 経営基盤の強化等を目的として漁協 合併が全国的に促進されるなか，1994年 1 月に富 戸漁協の伊東市漁協への合併が実施されたのに伴 い, 従来の「村」的な漁協運営が否定される事態 が生じるに至った。すなわち, 富戸のダイビング 事業による年間 2 億円を超える収入が，伊東市漁 協（本所）の収入として処理され，富戸支所への 利益配分が皆無となったのである。現在まで，こ らした伊東市漁協の措置を不服とする多くの富戸 区在住組合員が，ダイビング収入の富戸支所への 配分を求めてきたが，いまだに実現されていない 状況である。とくに合併後は漁協による組合員へ の配当金の支給も汪とんどなく，その意味でも組 合員の不満は大きい。一戸権所有者から構成され る「富戸財産管理組合」25）が所有し，実質的に は旧富戸漁協が管理してきた土地の賃貸料をめぐ る訴訟26）も, 富戸区在住組合員の伊東市漁協に 対する不満の表れの一つとして理解できる。

こうした富戸区と伊東市漁協との対立は, 共同 漁業権を法人としての漁協の「営業権」に純化さ 
れたものと理解するか, 元来の入会権的側面を認 めるかという，基本的な論点を含んでいる。つま り, 江戸時代以来, 漁村では「一村専用漁場」の 慣行が現在まで継承されて扣り，地先漁場を総有 してきたとする立場にたてば，共同漁場でのダイ ビング収入は漁協合併後も「地先権」27）を有す る漁村集落に帰属するが，そうした入会権的な側 面を認めなければ，当然ながらダイビング収入の 全額が合併後の漁協に帰属することになる。

法律論的には，いまだに $2 つ の$ 見解が対立した 状況が続いているが28), 伊豆半島のダイビングス ポットについての実態調査を実施した田中 (1993, p.14）が指摘するように, 実態としては大部分の ダイビングスポットでは「一村専用漁場」の慣行 が今でも存続し，その権利に基づいて「水面利用 料」が徴集されている。そして，ダイビングス ポット利用料が海の入会権に基づく「水面利用 料」としての性格を有する限りは, 浜本・田中 （1997，p.118）が主張するように，その収益は漁 村集落（旧来の村落社会としての富戸区）に帰属 すると考兄るべきだろう。

また，ダイビング収入の全額が伊東市漁協に㷌 属し続けた場合, ダイバー流入に伴らネガティブ な影響をも被っている地元の地域社会の反発が一 段と強まることが予想される。とくにダイビング 事業は, 漁協に多額の収益をもたらし, 一部の漁 業者・宿泊施設経営者に対しても一定の利益を与 えてはさたものの, 地域社会全体に必ずしも利益 が十分に還元されてきたわけではないため，な接 さら反発が強まる危険性が高いといえる。沼津市 大瀬崎地区では, 現在の共同漁業権を有している 内浦漁協が，合併前に共同漁業権を所有してきた 江梨区 (旧江梨地先漁業会) に対してダイビング 収入の約半分を配分して持り，それらは道路整備 等の公益的事業の地元負担金等として使用される など，実際にダイビング収入を生み出している地 域の生活基盤の整備に役立てられている（池・有 賀，1999，p.14）。そして, こらした利益の地元 地域社会への還元が，ダイビング事業に直接的に 関わらない住民の不満を解消するための安全弁と して重要な機能を果たしている。したがって, 法 律論からだけでなく、こうした地域社会論的な視
点からも, ダイビング収入の地元地域社会への還 元が検討されるべきであろら。

さらに,「合併後, 漁協のダイビング事業への 対応が悪化した」とのダイバーの指摘からも窥わ れるように29)，漁協合併がダイビング事業そのも のへ与える悪影響も心配される。現在では, ダイ ビングスポット間の集客競争が激化するなか, い かにダイバーに快適なサービスを提供できるか が，ダイビング収入の増減を左右するポイントと なりつつある30)。したがって，合併後の混乱に伴 らダイバーへのサービス低下は，ダイビング事業 の展開にとっての致命傷ともなりかねない。こう した点からも, 今後, 伊東市漁協によるダイビン グ事業のあり方が再検討される必要があろう。

\section{V おわりに}

富戸地区に扣けるダイビング事業の展開は, 漁 協に多額の収益をもたらし経営の安定化に大きく 貢献するとともに，ボートダイビング営業を通じ て漁業者にも一定の収入を保障している。また漁 協は, タンクのエア充填業務を掌握して利益率を 高める一方で, ダイビングサービスに対する優遇 措置を講じてダイビングサービスの経営にも配慮 し，それは結果として富戸地区のダイビング事業 全体の発展につながっている。その意味に打いて は, 漁協・漁業者とダイバー・ダイビングサービ スとの間には一定の共存関係が形成されており，

こうした共存関係の成立が富戸地区を全国有数の ダイビングスポットにまで成長させた基本的要因 だと言っても過言ではない。

しかし、こうしたダイビング事業の展開が，観 光地域としての富戸地区の発展に対して十分な貢 献をしてきたとは，残念ながら言いがたい。富戸 地区では, 沼津市大瀬崎地区などとは異なりダイ ビングサービスと宿泊施設が個々に独立した経営 を行っているため, 当初から両者の経営面での関 係が薄い。しかも近年では, ダイビングサービス による宿泊サービスの提供が一般化し，ダイバー 客を主体としてきた旅館・民宿の経営が著しく脅 かされつつあり，ダイビングサービスと宿泊施設 との関係は次第に悪化しつつある。とくに, ダイ ビングサービス経営者は, 観光地域全体の振興を 
目的としたイベント等に対して対応が一般に冷や やかなため, 宿泊施設経営者の不満をより助長す る結果となっている。その意味で, 大瀬崎地区の ような宿泊施設・ダイビングサービス結合型のダ イビング観光地に比べて, 富戸地区のような宿泊 施設・ダイビングサービス独立型のダイビング観 光地は，観光地域としての発展を図るらえでより 困難な課題を抱えていると言えよう。

また，一般の富戸区民にとっても，伊東市漁協 との合併後は漁協運営に対する影響力が大きく失 われる一方，ダイビング収入が公益的事業を行ら 際の地元負担金等として利用されることもなく， ダイビング事業の展開が地域社会の発展につな がっていないことへの強い不満がある。こうした 不満を解消するためにも, 少なくとも漁協のダイ ビング収入の一部を地元地域社会へ還元するよう な配慮が必要であろう。

スキューバダイビングの普及に伴い，全国各地 でダイビングスポットの開設が進められた結果, すでにダイバーがダイビングスポットを多面的に 評価し，選別する時期に入っている。もはや，海 中景観の美しさ等の自然条件の良さに依存するだ けでは多くのダイバーを集めることができず，良 好なダイビング施設の充実やダイバーに対する良 質なサービスが集客の決め手となりつつある。そ らした意味からも，ダイビング事業に直接的には 関係しない人びとをも含めた，地域社会全体の協 力体制づくりが不可欠であり，それがダイビング 観光地としての持続可能な発展の基本的な条件之 なるのではないだろらか。富戸地区の今後の動向 に期待したい。

\section{注}

1) Cカード発行枚数の累計をダイビング人口とみな した。Cカード (Certificated Card) とは, 潜水 の技能・知識を習得した認定証として潜水指導団体 から発行されるもので（日本海洋レジャ一安全・振 興協会編著, 1997, p.11〜12), ファンダイビング （スクール以外のダイビング）を行うにはC カード が必要である。スキューバダイビング人口を把握す る上では，Cカードの発行枚数が唯一のデータと なっている。

2) 最も重要な社会問題の一つとして, 漁協による潜
水料の徵収の是非をめぐる問題があげられよう。こ の問題について, 現在, とくに多くの関係者の注目 を集めているのは，1993年に潜水料の徵収が不当利 得であるとして，あるダイバーが内浦漁協（沼津 市）を相手に約 440 万円の損害賠償を求めた訴訟の 行方である。一審判決では原告側の請求が棄却され たが，二審では「潜水料徵収に法的根拠はない」と して漁協に既納の潜水料約10万円を原告に返却する よう命じる判決が下され，最高裁まで持込まれた。 2000年 4 月 21 日に最高裁は「審議不尽として高裁に 差し戻す」との判決を下し，いまだ潜水料徵収の是 非をめぐって係争中である。な拉，この経緯につい ては田中（2000）に詳しい。

3 ) レジャーとしてのスキューバダイビングは, 沿岸 海域の共同漁業権を有する地元漁協によって正式に 活動が認められた海域，すなわち「ダイビングス ポット」に损いて行われる。ダイビングスポット は，良好な海中景観，透明度の高さ，魚種の豊富さ などダイバーにとって鬽力的な自然条件を備え，し かる地元漁協・漁業者のダイビングについての理解 が得られた場合にのみ開設され得る。ダイビングス ポットが開設された海域の中には複数のダイビング ポイントが設定されるが, 通常は海中景観に優れ, しかも漁業活動との競合が問題とならない場所が選 ばれる。ダイビングスポットには, 短期間のダイビ ングを頻繁に楽しむ大都市近接型のものと, 比較的 長期に滞在するが頻度は少ない低緯度島嶼型（国外 を含む）の 2 種類が存在する（池・有賀， 1999， p.5)。

4 ) 高級魚ボラの漁は, 寛永期から紀伊徳川家の網と して既に行われていたといわれる。1872（明治 5) 年に部落張となって以降, ボラ網は富戸区に括ける 部落共同体の直轄下に括かれ, 部落の有力者から選 ばれた「つもと」を中心に経営管理された（大野， 1959, p.157 165)。ボラ漁については, 静岡県教 育委員会編（1988）拈よび田畑（1995）に詳しい。

5 ) 富戸は，海の街道筋を通して東京と商品流通の面 で直結していたが、ローカルな市場とのつながりは 殆どみられず，周辺の市場に対して孤立した形をと り，東京の資本はこのように孤立した富戸を直接的 にとらえていた。それが，自動車道路が開通して陸 上交通の網の目に組込まれて以降, 魚類や商品作物 の販売を通じて, 近隣地域や伊東・沼津などの地方 都市の市場との結びつきを強めた。その結果, 「出 物分一，入物分一」といった商品流通に関する部落 
の制約がなくなり，「一戸権」(後述) という部落 内の特権も相対的にその意味が薄くなり，平気で金 銭で売買されるようになっていった（大野，1959， p.217 222)。

6) 富戸区の所有する入会林野は約170hakのぼった が，1957年に東拓観光開発に約30haを売却し，他の 土地は全て「町内」単位に分割して配分された。郷 戸町に現在約 6 haの山林が残されている以外, 各町 内に配分された土地は全て売却された。最近まで共 有地を維持していた岡町では，1989年に土地を売却 し，1 戸当約2000万円が分配された。

7 ）静岡県熱海財務事務所資料比よ。伊豆高原のみ の観光客数についてのデータは不明である。

8 ）1968年に新築された富戸公民館の 2 階を利用した 宿泊施設 (60名収容)。1994年, 現在のコミュニ ティーセンターの建設を機に廃業した。

9 ) 伊豆高原全体では約 120 軒のペンションが存在す るといわれるが，筆者の調査能力とスキューバダイ ビングとの関連性を考壳た結果，富戸地区のらち国 道135号線よりも海側の地域に存在するペンション のみを調査対象とした。

10）23軒のペンションのらち, 現経営者の夫が富戸区 出身者であった 1 軒を除き，全てのペンション経営 者は東京大都市圈を中心とする都市部の出身者であ る。

11）旧富戸漁協が共同漁業権を有する共同漁場は広 く, 海岸線の長さにして約10kmに及ぶため, ダイビ ングスポット開設に伴ら漁業への影響はほとんど心 配されず，漁協総会でもさしたる反対はなかった。 海洋公園のダイビングスポットの賃貸料は, 現在で も年間100万円ときわめて安価であるが，これは伊 豆海洋公園ダイビングセンターが富戸地区の来訪ダ イバー数增加のために果たしてきた今までの貢献を 高く評価した結果だといわれる。

12）1993年には，一時的な預金高の増加に伴い，信用 事業収入の占める割合が例年よりも10\%程度高く なっている。したがって, 通常年の場合には, 事業 收益に括ける利用事業の割合は20\%近くにのぼると 推定される。

13）宮内（1998，p.307）は, 講習や海中でのガイド サービスなどのソフトや潜水器材の販売・レンタル などのハードをダイバーに提供する事業所である 「ダイビングショップ」を，一般的に都市部に括い て講習や潜水器材の販売を中心に事業を展開してい る「ダイビングプロショップ」と, ダイビングポイ
ントに近い場所に店舗を開設し，ダイビングガイド や潜水器材のレンタルを中心に事業展開している 「ダイビングサービス」に区分している。本稿でも この定義に従った。

14）一方で，タンクのエア充填業務は, 設備投資が必 要なら光機器の維持・管理に専門的な知識が必要な ため，小規模なダイビングサービスの中には，むし ろタンク業務を敬遠する傾向も強い。

15）ただし，伊豆半島東海岸は，温泉観光地としても 有名であるため，とくに土日や休日には道路の交通 渋滞が著しい。交通渋滞により, 東京大都市圈から の距離が短い割には，予想外に自動車での移動時間 がかかる場合が多い。

16）とくに春〜夏が繁忙期である講習は，1 日当りの 受入人数が圧倒的に多く, ダイビングショップに とっては荒天による潜水禁止のため講習を開催でき ない場合の収益面・信用面での損害が大きい。講習 の開催は, 潜水器材の販売促進にとっても重要な役 割を担って赫り，大手のダイビングショップでは大 きな収入源として重視されている。

17）漁協自営のボラ漁・イルカ漁, 定置網に主に利用 する漁船で，このうち動力船が 4 隻を占めている。

18）漁業者の中には, 接客を伴らボートダイビング営 業を好まない人も多い。20隻の一本釣漁船のらち ボートダイビング営業を行ら漁船が 13 隻に止まって いるのは,こうした個人的な理由による所が大き い。

19）指定されたポイントまでダイバーを案内し，ダイ ビング終了後に富戸港までダイバーを送り届けるだ けなので, 漁労に比べて労働量・労働時間とも少な い。また「ハーフボート」（1 人当り 1 回500円, 漁 協手数料なし）の場合は，ポイントまでダイバーを 案内するだけで帰港でき，効率的である。

20）ボート利用客に対しては, タンク賃貸料を 1 本当 り半額の1000円に値引きしているほか, 施設使用料 も半額（12〜2月は無料）にしている。

21）ダイバーは金曜日の午後11時頃に到着する場合が 多く，行動時間について他の一般客とのズレが大き い。また,「水着のまま旅館内を歩き回られては困 る」といら理由でダイバーの宿泊を嫌う経営者もい る。

22）宿泊施設を営業するためには，旅館業法の定める ところにより旅館営業・簡易宿所営業等の営業許可 を保健所から受けなければならない。しかし，ダイ ビングサービスでは営業許可を受けずにダイバーを 
有料で宿泊させているため, 旅館・民宿経営者は大 きな不満を抱いている。ダイビングサービス側は， 宿泊・ガイド等を含めたパック料金を設定し、「料 金は宿泊料ではなくダイバーへの接待料として受領 している」との説明を保健所行っている。

23）ダイビングサービス経営者のらち富戸区出身者は 1 名に過ぎず, 東京大都市圈からの転入者が圧倒的 に多い。また，旅館・民宿はダイバーに対する宿泊 料金の值引きは行ってきたが, 特定のダイビング サービスと宿泊施設との間で宿泊客の斡旋をめぐる 契約が結ばれたケースはなく，もともと相互依存関 係が薄い。

24）一戸権は，富戸区に伝統的に一戸を構える正式の 構成員といら性格を持ち，一戸権を持たない世帯は 「半戸」と呼ばれた。したがって，入会林野の売却 による莫大な収益の配分を受けたのも一戸権を所有 する世帯のみであり，一戸権を持たない世帯からの 不満も強い。一般に本家に当る世帯は一戸権を所有 しており，分家も一定の金額を区に支払らことに よって一戸権を獲得することができたが, 複数株の 所有は禁止されていた。売買価格は，1946年当時で 3000円であった。

25）行政組織としての富戸区と共有財産を管理する一 戸権所有者集団とを明確に区別するため，1957年に 当時の一戸権を所有する321戸で富戸財産管理組合 が設立された。現在, 理事 6 名（うち5名は 5 町内 から 1 名ずつ選出され総会で信任を受ける), 監事 2名の役員によって運営されている。1997年度の歳 入は, 約 4800 万円（うち土地売却金等による前年度 繰越金約4570万円を含む)であった。

26）漁協施設や魚付保安林として利用されている海岸 沿いの土地は，かつての富戸区の共有地（約22ha） であった。1957年以降, 富戸財産管理組合の所有地 となったが，実質的には引続き漁協が管理してき た。伊東市漁協との合併に伴い, 漁協が使用してい る約1.4haの土地について漁協と財産管理組合との 間で貸借契約が結ばれたが，1996年 8 月までの賃貸 料の納入をめぐって両者が対立し, 現在も係争中で ある。

27）浜本（1996）は，共同漁業権が設定されている漁 村の地先水面を「われわれの海」と呼び，漁協がそ の地先水面の利用を管理・調整する「慣習」に対し て「地先権」という名称を与えている。いわば地先 権とは, 明治期の漁業改革によって剥ぎ取られた入 会慣行のことを意味する。
28）共同漁業権は漁業協同組合にのみ㛿属するのかそ れとも組合員の総有かといら基本的な問題がある。 共同漁業権は入会権的なものであり，管理権能は組 合に帰属するが，実質的な收益権能は個々の組合員 に帰属するといら，いわゆる「総有説」と，共同漁 業権は法人たる漁業協同組合に帰属し, 組合員の漁 業を営む権利は, 漁業協同組合といら団体の構成員 としての地位に基づいて行使する社員権的権利であ るとする，いわゆる「社員権説」とが対立している (三好, 1995，p.15)。

29）例えば, ダイビング施設の修繥についても, 合併 後は伊東市漁協（本所）の許可を得て実施されるた め, 対応が非常に遅くなったといらダイバーの声が 聞かれる。

30）実際に, 伊豆海洋公園では, 1998年頃から順次 シャワールームの改良工事やビーチエントリーのた めのスロープの整備を進め, それが来訪ダイバー数 の増加につながっている(第2図)。

\section{文献}

富戸史話編集委員会編（1969）：『私たちの郷土 富戸 史話』. 富戸史話編集委員会, 170p.

浜本幸生 (1996)：『海の「守り人」論一徹底検証・漁

業権と地先権一』. れんが書房新社, 462p.

浜本幸生・田中克哲（1997）:『マリン・レジャーと漁

業権』. 漁協経営センター, $165 \mathrm{p}$.

葉室和親 (1978): 大室山火山群の地質. 地質学雑誌, 84-8, pp.433-444.

池俊介・有賀さつき (1999): 伊豆半島大瀬崎におけ

るダイビング観光地の発展. 新地理, 47-2, pp.122.

伊東市 (1989): 『地域営漁計画書』. 伊東市, 52p.

伊東市史編纂委員会編（1958）：『伊東市史』. 伊東市 教育委員会, $1052 \mathrm{p}$.

経済企画庁編 $(2000): 『$ 平成12年版 日本経済の現 況』. 大蔵省印刷局, 425p.

マリン企画 (1997):『ダイバーズ天国ニッポン』. マ リン企画, 303p.

宮内久光 (1998): 島嶼地域に和けるダイビング観光 地の形成と人口現象一沖縄県座間味村を事例とし て一. 琉球大学法文学部人間科学科紀要「人間科 学」, 1, pp.299-335.

三好登 (1995): 漁業権の内容と法的性質. 日本土地 法学会編『漁業権 - 行政指導 - 生産緑地法』. 有斐 閣, pp.10-18. 
日本海洋レジャ一安全・振興協会編著（1997）:『レ ジャー・スキューバ・ダイビング一安全潜水のすす め一』. 成山堂書店, 204p.

小栗宏 (1983):『日本の村落構造一林野と漁場の役 割一』. 大明堂, $248 \mathrm{p}$.

大野盛雄 (1959) : 伊東市富戸に抢ける経済地理学的 研究. 東大東洋文化研究所紀要, 18, pp.135-255.

静岡県漁業組合取締所 (1894):『静岡県水産誌 巻 四』. 静岡県漁業組合取締所, $182 \mathrm{p}$.

静岡県教育委員会編（1988）:『富戸の民俗一伊東 市一』. 静岡県, $125 \mathrm{p}$.

田畑正徳 (1995):『富戸ボラ漁物語』. 私家版, 35p. 田中克哲（1993）：ダイビング・スポット開設と利用
料徵収の法社会学的考察一伊豆半島地域を事例とし て一. 漁業経済研究, 38-1, pp.1-18.

田中克哲 (2000): 潜水料徵収の是非をめぐって一大 瀬崎ダイビング訴訟, 最高裁で差し戻し判決一, 漁 協経営, 448, pp.15-19.

運輸省海洋・海事課（1989）: 『海洋性レクリエーショ ンの現状と展望』. 運輸省, $178 \mathrm{p}$.

山村順次 (1974): 大都市周辺における観光開発. 浅 香幸雄・山村順次編著『観光地理学』. 大明堂, pp.152-165.

山下正貴 (1992)：沿岸漁場における海面利用調整に ついて一相模湾を事例として一。漁業経済研究, 37-3, pp.25-40. 


\title{
The Change of the Community due to the Introduction of Scuba Diving in Futo, Ito City.
}

\author{
Shunsuke IKE*
}

Key words: Ito City, scuba diving, tourist area, community, coastal village

The purpose of this paper is to examine the change of rural community with the introduction of scuba diving in the settlement of Futo in Ito City in Shizuoka Prefecture as a typical case of a tourist area for divers. The results are as follows.

1. The inhabitants on Futo have depended upon coastal fishery and subsistence farming, forming a tight rural community. But the occupational structure of this region has been changed remarkably by its development as a tourist area since the 1960s.

2. After the opening of a diving spot of Izu-Kaiyo-Koen (Marine Park of Izu) in 1964, the number of divers has rapidly increased. The Futo fishermen's cooperative began to open more diving spots expanding a diving business in 1988. And now, there are about 94,000 visits by divers per year.

3. In Futo, many diving service shops have been established after the 1990s and 35 shops are in business now. The scale of each shop is generally small. And the main business of many shops is diving guide service under the sea, because all diving shops except two shops are prohibited to filling tanks with air as a service for divers by the fishermen's cooperative.

4. The fishermen's cooperative has made a lot of profit by levying a charge on each diver and lending air tanks to divers. Fishermen also earn income by transporting many divers to diving points. But recently, the income of hotels and minsyuku (cheap lodging house in tourist resorts) is declining, because many diving service shops are offering lodging service for divers without permission.

5. Fishermen's cooperative of Futo was amalgamated by Ito City fishermen's cooperative in 1994. Members of the community of Futo feel an antipathy against the Ito City fishermen's cooperative since the fishermen's cooperative does not return profit from the diving business on Futo to the community. Therefore, the sutbor considers that the fishermen's cooperative should return profit to the community which accept many divers for the development of its community.

\footnotetext{
*Shizuoka University
} 